\title{
ЭФФЕКТИВНОСТЬ ВЫДЕЛЕНИЯ ЛОВУШЕК УВ СЕЙСМОРАЗВЕДКОЙ МОВ В СЕВЕРНОЙ ЧАСТИ ТИМАНО-ПЕЧОРСКОЙ НЕФТЕГАЗОНОСНОЙ ПРОВИНЦИИ
}

Вазаева A.A., Екиненко А.В.

(ОАО «Нарълн-Марсейсморазведка»)

В докладе рассмотрены основные титы ловушек углеводородов, характерные для ТиманоПечорской нефтегазоносной провинция. Показана связь их формирования с тектонической историей развития ТПП. Также в докладе рассматривается динамическая интерпретация как инструмент повышения зффективности прогноза коллекторских свойств ловушек.

За дпительный период изучения ТиманоПечорской провинция (ТПП) был выполнен значительный объём геолого-геофизических исследований. В результате этих работ выделены локальные структуры и неантиклинальные ловушки (НАЛ) углеводородов (УВ). В северной части ТПП выявлены многодисленные тектонически-, литологически- и стратиграфически-экранированные ловушки.

Наиболее благоприятные условия формирования тектонически-экранированных ловушек УВ имеются в зонах сочленения мобильных и стабильных геоструктур территории. К таким зонам относятся сочленение Печоро-Колвинского авлакогена с западным склоном Большеземельского свода и с Малоземельско-Колгуевской моноклиналью, сочленение Большеземельского свода и ВарандейАдзьвинской структурной зоны [1].

Структурно-стратитрафические ловушки развиты в области сочленения Колвинского грабена с западным склоном Бомьшеземельского свода. Здесь выходят под предцжьерский размыв или выклиниваются отложения в интервале от силурийских до среднедевонских - формируются НАЛ. В пределах восточного склона Большеземельского свода в результате предраннефранкского размыва последовательно срезаются пачки лохковского яруса нижнего девона. На временном разрезе в зоне выклинивания наблюдается ослабление динамнческой выразительности отражения и присутствие интерференции. К каждой линия выклинивания приурочен ряд НАЛ структурно-стратиграфического типа. В частности к пачкам «а» и «б» приурочены наиболее высокоёмкие коллектора на месторождениях Требса и Титова. Перспективные ловушки УВ, оставшиеся неразбуренными, сосредоточены как в пределах сухопутной части ТПШ, так и в Печорском море.

В северной части ТПП широко распространены ловушки УВ, связанные с органогенным постройками. В нижнесилурийских отложениях выделяются структурно-литологические ловушки, связанные с карбонатными образованиямн, образующими в волновом сейсмическом поле эффекты, характерные для останцов.

Опыт проведения сейсмических работ МОВ ОГТ показал, что полученный сейсмический материал, обработанный по стандартному графу, позволяет выделять и оконтуривать в первом приближении ловушки УВ различного генезиса. Прогноз коллекторских свойств и распределения коллекторов по площади возможен на основе расчета динамических параметров и AVO-анализа [2].

Изучение нефтеперспективньт объектов в TIII позволяет говорить, что расчёт динамических параметров и AVO-атрибутов действительно несет информанию о коллекторских свойствах органогенньгх построек. На картах атрибутов выделяются аномальные области, которые свидетельствуют о возможном нефтепроявлении. Далее приведен пример сейсмического атрибута иотносительный импеданс", где в районе месторождения наблюдается аномально низкое значение импеданса и те же пониженные значения набмодаются в районе прогнозируемой залежи, что вполне может говорить о возможной нефтенасыщенности (Рис.1).

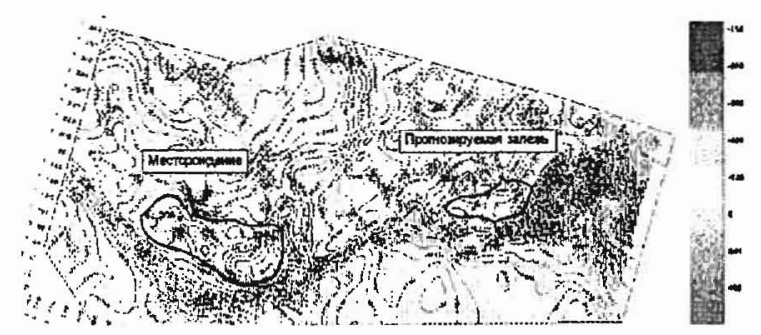

Рис.1 Карта сейсмического атрибута «относительный импеданс»

В целом, накопленный опыт динамической обработки сейсмической записи свидетельствует о возможности наиболее надежного прогноза коллекторских свойств пород с помощью расчетов сейсмического импеданса, мгновенных частот и геометрических параметров сейсмической записи. Наряду с очевидными успехами сейсморазведки МОВ ОГТ при выявлении ловушек различного генезиса и определении их основных параметров, имеются и определенные проблемы, к которым, прежде всего, следует отнести не всегда оптимальное соотнотение ситнал/помеха, отсутствие данньх о скорости поперечных волн, недоучет эффекта анизотропик, отсутствие во многих скважинах даннњх плотностного каротажа.

\section{ЛИТЕРАТУРА}

Геология и нефтегазоносность Севера европейской части СССР. Под ред. Ю. А. Россихина, Тюмень 1990.

Изучение изменений амплитуд сейсмкческих отражений дтя поисков иразведки залежей углеводородов. Учебное пособие для вузов. Воскресенский Ю.Н.М.: РГУ нефти и газа, 2002 